\title{
Breeding and Cannibalism Behaviours of Captive Coronella austriaca (Colubridae) in a
}

\section{Terrarium}

\author{
İbrahim UYSAL ${ }^{1}$, Çiğdem GÜL ${ }^{2 *}$, Murat TOSUNOĞLU²
}

\begin{abstract}
Cannibalism involves consuming all or part of another individual of the same species as food. Consuming the same species, or showing cannibalistic behaviour is common in reptiles, especially in snake species. The captured female Coronella austriaca of the Colubridae family was kept in captivity for two months in the terrarium. The female sample fed on one of the offsprings after ovoviviparous delivery. In the following observations it was determined that one of the juvenile individuals fed on another juvenile with similar size. The objective of this study is to provide information about the breeding and cannibalistic behaviour of Coronella austriaca under captivity.
\end{abstract}

Key words: Coronella austriaca, Cannibalism, Maternal cannibalism

\section{Kaptivite Altındaki Coronella austriaca (Colubridae) Türünde Üreme ve Yamyamlık Davranışı}

ÖZET: Sürüngen türleri içerisinde özellikle yılan türlerinde kanibalizm yani aynı türe ait bireylerin yenmesi yaygın durumdur. Çalışmada yakalanan Colubridae familyasına ait olan dişi Coronella austriaca bireyi iki ay süre ile teraryumda tutulmuştur. Dişi bireyin ovovivipar doğumunun ardından, ebeveynin yavrularla ve yavruların da kendi arasındaki kanibalizm davranışları gözlemlenmiştir. Yapılan çalışma Coronella austriaca türünde üreme ve kanibalizm davranışı ile ilgili bilgiler vermektir.

Anahtar Kelimeler: Coronella austriaca, Kanibalizm, Maternal Kanibalizm

\footnotetext{
1 İbrahim UYSAL (Orcid ID: 0000-0001-9790-9541), Health Services Vocational School, Çanakkale Onsekiz Mart University, 17100, Çanakkale, Turkey, e- mail: uysalibrahim@windowslive.com.

${ }^{2}$ Çiğdem GÜL (Orcid ID: 0000-0001-9790-9541), Murat TOSUNOĞLU (Orcid ID: 0000-0001-9790-9541), Department of Biology, Faculty of Arts and Sciences, Çanakkale Onsekiz Mart University, Çanakkale, Turkey

*Sorumlu Yazar / Corresponding Author: Çiğdem GÜL, e-mail: gulcigdem@comu.edu.tr

A part of this study was presented as a poster in the "ISEEP-2017 VIII. International Symposium on Ecology and Environmental Problems (12-15 Eylül 2017) and published in the congress book as an abstract text. 


\section{INTRODUCTION}

Cannibalism is an important and common behaviour affecting population structure, living conditions, competition, resources and behaviour of individuals (Polis, 1981; Polis and Myers, 1985; Mitchell, 1986; Göçmen et al., 2008). Age, size, sex, density of conspecifics, available food, degree of relatedness and other factors all may influence the occurrence and the magnitude of cannibalism to various degrees (Fox, 1975; Polis, 1981). In most species of reptiles, cannibalism appears to occur opportunistically as a by-product of normal predatory behaviour (Polis and Myers, 1985).

Maternal cannibalism involves the consumption of offspring by the female parent and can be further categorized as either the consumption of non-viable offspring (eggs, undeveloped ova or stillborn neonates) or of living offspring (Mocino-Deloya et al., 2009). Maternal cannibalism has been described from a number of animal species, including numerous reptiles (Huff, 1980; Polis and Myers, 1985; Kevles, 1986; Somma, 1989; Somma, 2003; Mitchell and Groves, 1993; Lourdais et al., 2005). Many reptile species where males protect eggs, sometimes they consume some of the eggs they protect (Rohwer, 1978; Petersen and Marchetti, 1989; Thomas and Manica, 2003). Eggs and newborns are rich in nutrients (Polis, 1981; White, 1991; Speake et al., 2003). Postnatal females weaken and take several weeks to heal. For this reason, the ingestion of especially non-living offspring may provide energy to the female, but also help restore the body's muscular system (Lourdais et al., 2005).

Cannibalism is more common in reptiles, especially in snakes (Mitchell, 1986; Mori and Moriguchi, 1988). In nature, cannibalism is especially frequent among fossorial snakes and Ophiophagous snakes (Gasc, 1994). The cannibalism behaviour in Clelia, Malpolon, Bungarus and Ophiophagus genera has been reported (Saint-Girons, 1994). Dolicophis jugularis may also possess potential cannibalistic behaviour (Göçmen et al., 2008). Lisicic et al. (2011) observed and photographed that Hierophis gemonensis species ate the same species of similar size during field study. Mienis (1986) reported cannibalism among juveniles of the genus Coluber jugularis in Israel.

Coronella austriaca, lives in meadows, on stony slopes and in bushy landscapes alongg forest edges. They move slowly, calmly and are nonvenomous and harmless. They usually feed on lizard species, small birds and rodents, from the family of Colubridae, which are about $75 \mathrm{~cm}$ in length (?). Backside ground colour may be in light brown tones and occasionally close to red. There are darker sparse and scattered lines on the back than the ground colour. On the sides of the head, there is a dark stripe that runs from the nostrils to the neck (Tosunoğlu et al., 2017).

The aim of this study is to provide general information and observations about the breeding and cannibalistic behaviour of Coronella austriaca under captivity.

\section{MATERIALS AND METHODS}

The female individual of Coronella austriaca was caught using the snake stick in the rocky habitat with sparse vegetation around Tödürge-Sivas (Turkey) (37S380627; UTM: 4412834; elevation: $1313 \mathrm{~m}$ ) on 09.07.2014 (Figure 1). The captured specimen was kept under semi-captivity for 2 months in the terrarium, measuring 50x70 $\mathrm{cm}$, prepared in accordance with the habitat requirements of the species. Body length measurements of female and offsprings were performed with Mitutoyo digital calliper and weight measurements were made with precision scales. The images of the offsprings and cannibalism were recorded with a digital camera. Samples were included in the collection of Çanakkale Onsekiz Mart University Zoological Museum. 


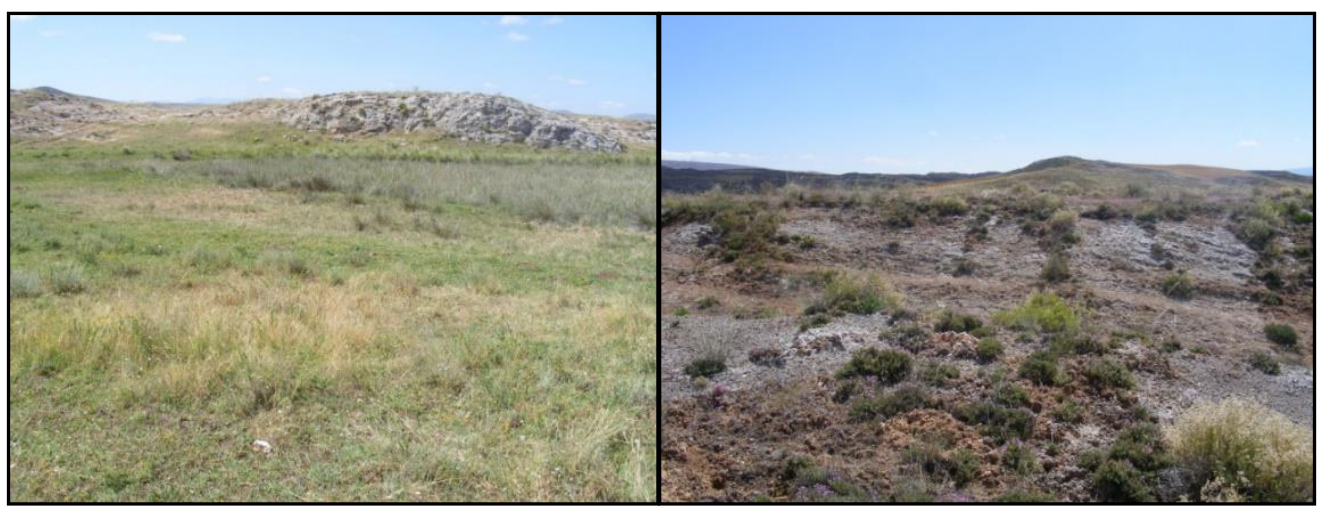

Figure 1. Localities of Coronella austriaca specimens.

\section{RESULTS AND DISCUSSION}

The total body length of the female Coronella austriaca specimen was $52.5 \mathrm{~cm}$ and head + body length was $45 \mathrm{~cm}$ respectively. Specimen was fed with a small lizard for 8 days. This ovoviviparous specimen produced 7 offsprings approximately after one month of captivity. The weight and body measurements of the offsprings immediately after birth are given in
Table 1. The mean weight of the offsprings was $6.32 \mathrm{~g}$, mean total body length was $176.3 \mathrm{~mm}$, head length was $8.21 \mathrm{~mm}$ and head + body length was measured as $144.74 \mathrm{~mm}$, respectively. Tenebrio molitor (mealworm) was placed in the terrarium and the offsprings were fed regularly. Cannibalistic behaviour started 35 days after birth where one offspring consumed another and the mother fed on one of the offspring 42 days after birth (Figures 2-3).

Table 1. The mean weight and body measurements of the offsprings

\begin{tabular}{lcccc}
\hline Offsprings & Weight $(\mathbf{g r})$ & Total body length $(\mathbf{m m})$ & Head length $(\mathbf{m m})$ & Head + body length $(\mathbf{m m})$ \\
\hline 1. Offspring & 6.154 & 176 & 8.70 & 139.46 \\
2. Offspring & 6.407 & 175 & 8.87 & 128.46 \\
3. Offspring & 5.923 & 174 & 7.24 & 148.88 \\
4. Offspring & 6.454 & 176 & 7.52 & 143.05 \\
5. Offspring & 6.633 & 175 & 7.83 & 147.32 \\
6. Offspring & 6.374 & 183 & 8.45 & 153.66 \\
7. Offspring & 6.303 & 175 & 8.86 & 152.36 \\
\hline Mean & $\mathbf{6 . 3 2 1}$ & $\mathbf{1 7 6 . 3}$ & $\mathbf{8 . 2 1}$ & $\mathbf{1 4 4 . 7 4}$ \\
\hline
\end{tabular}

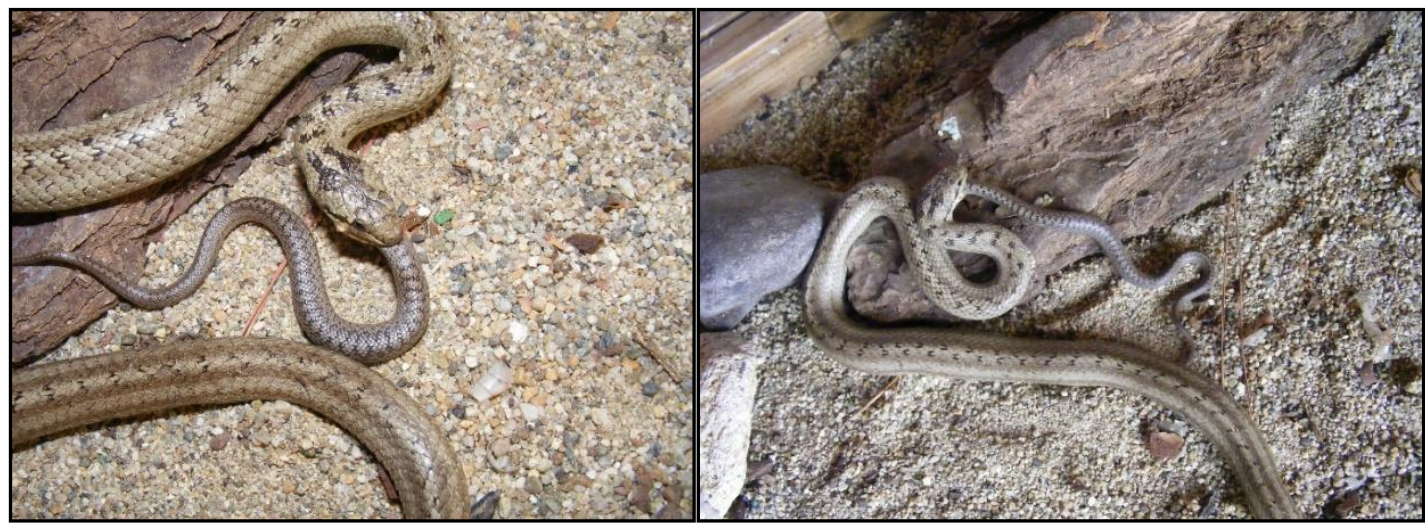

Figure 2. Maternal cannibalism 


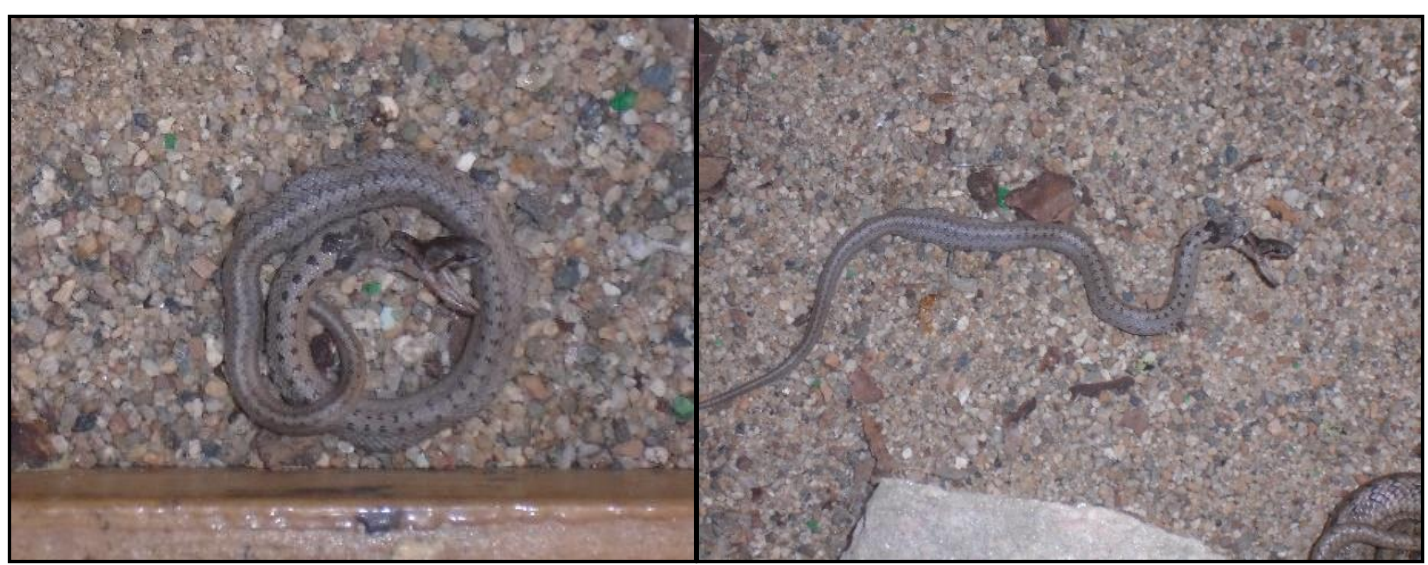

Figure 3. Cannibalism among juvenile individuals

Göçmen et al. (2008) reported cannibalism records of Dolicophis jugularis. He determined that cannibalistic behaviour was common for this species and that hunger could be the stimulating factor for this behaviour.

Martinez et al. (2006) studied, male and female Vipera latastei samples in the same terrarium and observed that the mother who gave birth to 5 offsprings first consumed the adult male and then gave birth to 2 more offsprings. During the field study, they found that the juvenile Vipera latastei feeds on juvenile Coronella austriaca with the same size. The same researchers reported that a small male individual was a stimulant for cannibalistic behaviour for the mother after birth in the terrarium, whereas Coronella austriaca was a potential prey in its natural environment.

Lourdais et al. (2005) suggested that the maternal cannibalism in Epicrates cenchria maurus of Boidae family is used to recycle wasted energy and reduce the time required for recovery from pregnancy. Mocino-Deloya et al. (2009) found that importance of maternal cannibalism in rattlesnakes, and suggest stronger support for the maternal recovery hypothesis than for the parental care hypothesis.

\section{CONCLUSION}

Cannibalism is an important behaviour that influences competition for resources and spouse selection (mating?), population structure, life history and habitat preferences of species. Mitchell (1986) suggested that cannibalistic individuals might suffer from a flaw in same species of recognizing mechanisms. If this phenomenon exists, it is possible to explain the occurrence of cannibalism in some species more often than others. It is stated by Heinen and Abdella (2005) that experimental studies focused on understanding the factors and mechanisms underlying cannibalism in reptile species will be more enlightening.

This study provides information about the breeding and cannibalistic behaviour of Coronella austriaca under captivity. Although they were fed in captivity, maternal cannibalism of Coronella austriaca was observed and it was determined for the first time that the juveniles fed on each other.

\section{REFERENCES}

Fox LR, 1975. Cannibalism in natural populations. Annual Review of Ecology, Evolution, and Systematics, 6:87-106.

Gasc JP, 1994. Predation and nutrition. In: R. Bauchot (ed.), Snakes A Natural History, pp. 108- 121, Sterling, New York.

Göçmen B, Werner YL, Elbeyli B, 2008. Cannibalism in Dolichophis jugularis (Serpentes: Colubridae): More than Random. Current Herpetology, 27(1): 1-7. 
Heinen JT, Abdella JA, 2005. On the advantages of putative cannibalism in American Toad tadpoles (Bufo a. americanus): Is it active or passive and why? American Midland Naturalist, 153: 338-347.

Huff T, 1980. Captive propagation of the Subfamily Boinae with emphasis on the genus Epicrates. In:SSAR Contributions to Herpetology No 1:Reproductive Biology and Diseases of Captive Reptiles (Ed.by J.B.Murphy\&J.T.Collins), pp.125-134. Lawrence,Kansas: Society for the Study of Amphibians and Reptiles.

Kevles B, 1986. Females of the Species: Sex and Survival in the Animal Kingdom. Cambridge, Massachusetts: Harvard University Press.

Lisicic D, Pocanic P, Lovric V, Derezanin L, Tadic Z, 2011. A case of cannibalism in Hierophis gemonensis: preying on conspecific adult. Hyla, 2: 35-36.

Lourdais O, Brischoux F, Shine R, Bonnet X, 2005. Adaptive maternal cannibalism in snakes (Epicrates cenchria maurus, Boidae). Biological Journal of the Linnean Society, 84, 767-774.

Martinez Freiria F, Brito JC, Lizana Avia M, 2006. Ophiophagy and cannibalism in Vipera latastei Boscá, 1878 (Reptilia, Viperidae). Herpetological Bulletin, 96: 26-28.

Mienis HK, 1986. Cannibalism in a juvenile large whip snake, Coluber jugularis asianus, in Israel. Zoology in the Middle East, 1: 88-90.

Mitchell JC, 1986. Cannibalism in reptiles: a worldwide review. SSAR Herpetological Circulars, 15: 1-37.

Mitchell JC, Groves JD, 1993. Intraspecific oophagy in reptiles. Herpetological Review, 24: 126130.

Mocino-Deloya E, Setser K, Pleguezuelos JM, Kardon A, Lazcano D, 2009. Cannibalism of nonviable offspring by postparturient Mexican lance-headed rattlesnakes, Crotalus polystictus. Animal Behaviour, 77: 145-150.
Mori A, Moriguchi H, 1988. Food habits of the snakes in Japan: a critical review. Snake, 20: 98-113.

Petersen CW, Marchetti K, 1989. Filial cannibalism in the cortez damselfish Stegastes rectifraenum. Evolution, 43: 158- 168.

Polis GA, 1981. The evolution and dynamics of Intraspecific predation. Annual Review of Ecology and Systematics, 12: 225-251.

Polis GA, Myers CA, 1985. A survey of intraspecific predation among reptiles and amphibians. Journal of Herpetology, 19: 99-107.

Rohwer S, 1978. Parent cannibalism of offspring and egg raiding as a courtship strategy. American Naturalist, 112: 429-440.

Saint-Girons MC, 1994. Snakes' enemies. In: R. Bauchot (ed.) Snakes A Natural History. pp. 172- 181. Sterling, New York.

Somma LA, 1989. Oophagous behavior in 'brooding' prairie skinks, Eumeces septentrionalis. Herpetological Review, 20, 3-4.

Somma LA, 2003. Parental behavior in lepidosaurs and turtles: source addendum. Bulletin of the Chicago Herpetological Society, 38, 65-76.

Speake BK, Thompson MB, Thacker FE, Bedford GS, 2003. Distribution of lipids from the yolk to the tissues during development of the water python (Liasis fuscus). Journal of Comparative Physiology B, 173: 541-547.

Thomas LK, Manica A, 2003. Filial cannibalism in an assassin bug. Animal Behaviour, 66: 205-210.

Tosunoğlu M, Gül Ç, Uysal İ, 2017. Çanakkale Amfibi ve Sürüngenleri. Orman ve $\mathrm{Su}$ İşleri Bakanlığı, ISBN: 9786058290617, pp. 1-71.

White HB, 1991. Maternal diet, maternal proteins and egg quality. In: Deeming DC, Ferguson MWJ, eds. Egg incubation: its effects on embryonic development in birds and reptiles. Cambridge: Cambridge University Press, 1-15. 